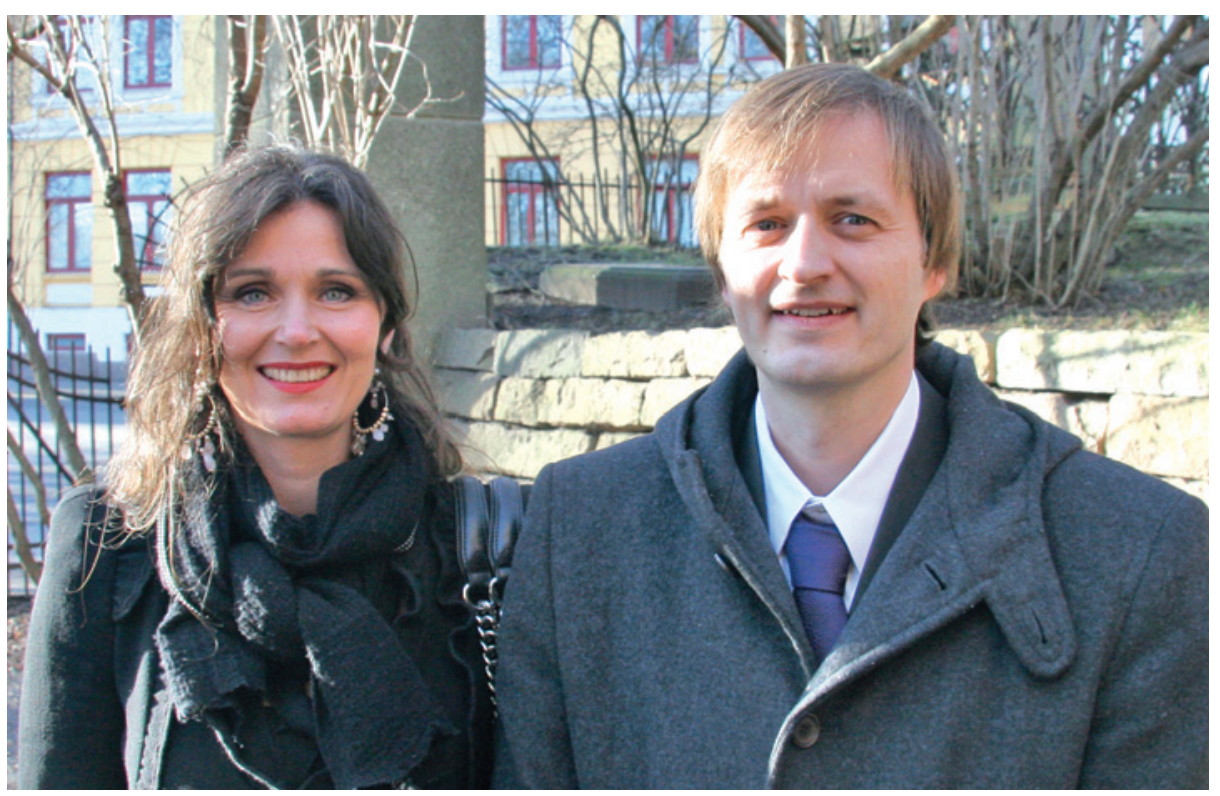

Mette Kalager og Michael Bretthauer, artikkelens første- og tredjeforfatter. Foto privat

\title{
Brystkreft er overdiagnostisert
}

$15-25 \%$ av dem som fikk påvist brystkreft ved mammografiscreening, hadde ingen nytte av behandlingen. Dette viser ny norsk studie.

Noen tilfeller av brystkreft som oppdages ved mammografiscreening ville aldri ført til symptomer eller død uten screening. Dette kalles overdiagnostikk. Problemet er lenge blitt ignorert, men det er nå en økende erkjennelse av at overdiagnostikk skjer ved mammografiscreening.

Norske forskere har nå estimert graden av overdiagnostikk i det norske mammografiprogrammet (1). Insidens av brystkreft i norske fylker ble sammenliknet med og uten screeningprogram i perioden 1986-2005. Det ble brukt en liknende metode for justering av konfunderende faktorer og tidstrender som $i$ en tidligere studie om dødelighet av bryst$\operatorname{kreft}(2,3)$. Studien omfattet 39888 pasienter, hvorav 7793 ble diagnostisert etter innføring av mammografiprogrammet.

$15-25 \%$ av alle tilfeller av brystkreft som ble diagnostisert, var overdiagnostikk pga screening. Dette innebærer at rundt hver femte kvinne som fikk diagnostisert brystkreft i screeningprogrammet ikke hadde noen nytte av behandlingen - de ville ikke ha dødd av sykdommen om de ikke hadde møtt til screening.

- Våre data tyder på at i de ti årene mammografiscreening har pågått i Norge, har mellom 1169 og 1948 kvinner fått diagnosen brystkreft unødvendig. Kun 47 kvinner er blitt reddet fra å dø av brystkreft. Screeningprogrammet hadde ingen effekt på total dødelighet, sier Mette Kalager, artikkelens førsteforfatter.

\section{Om gruppen}

Artiklene er resultatet av tett samarbeid mellom norske forskere ved hhv. Universitetet i Oslo, Oslo universitetssykehus, Sykehuset Telemark og forskere ved Harvard University i Boston, USA. Gruppen er sammensatt av klinikere, epidemiologer og statistikere. I tillegg til screening for brystkreft arbeider gruppen også med problemstillinger innen forebygging av kolorektalkreft.

\section{Erlend Hem}

erlend.hem@medisin.uio.no

Tidsskriftet

\section{Litteratur}

1. Kalager M, Adami H-O, Bretthauer M et al. Overdiagnosis of invasive breast cancer due to mammography screening: results from the norwegian screening program. Ann Intern Med 2012; 156: 491-9.

2. Kalager M, Zelen M, Langmark F et al. Effect of screening mammography on breast-cancer mortality in Norway. N Engl J Med 2010; 363: 1203-10.

3. Hem E. Mammografi har liten effekt. Tidsskr Nor Legeforen 2010; 130: 1899

Publisert først på nett 10.4. 2012.
Ordforklaringer

Overdiagnostikk: Diagnostikk av en tilstand som aldri ville gitt symptomer eller ført til død.

Mammografiprogrammet: Norsk screeningprogram for brystkreft ved mammografi. Alle kvinner i Norge mellom 50 og 69 år blir innkalt hvert annet år

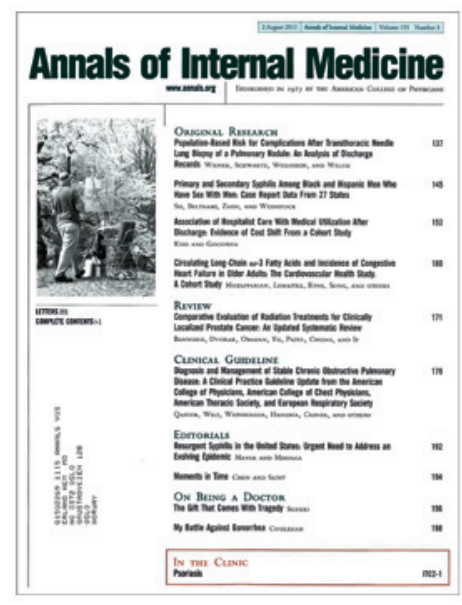

Artikkelen ble publisert 3.4. 2012 i Annals of Internal Medicine (www.annals.org) som regnes som en av de «fem store» innen medisinsk publisering ved siden av New England Journal of Medicine, JAMA, BMJ og The Lancet 